\title{
Pengaruh Jenis Biomassa Terhadap Karakteristik Pembakaran dan Hasil Bioarang Asap Cair dari Proses Pirolisis
}

\author{
Kemas Ridhuan, Dwi Irawan \\ Program Studi Teknik Mesin, Universitas Muhammadiyah Metro \\ Jl. Ki Hajar Dewantara 15 A Metro, Lampung. \\ kmsridhuan@yahoo.co.id - dwi_irawan12@yahoo.co.id
}

\begin{abstract}
Biomass is one of the most renewable energy sources we encounter around us, with many types. Biomass can be converted to various forms of energy one of which is pyrolysis combustion. Pyrolysis is a chemical decomposition of organic matter (biomass) through the heating process at high temperatures that occur without or little oxygen. The results of the pyrolysis process in the form of bio-charcoal and liquid smoke products. Each biomass has different characteristics and composition, so if burned it will produce different temperatures and pyrolysis products. The purpose of this research is to know the influence of biomass type on the combustion characteristics, the calorific value and the amount of bio-charcoal and the resulting liquid smoke. The method of this research is by using waste biomass of rubber shell, young coconut husk and rice sekan. Biomass is burned by slow prolisis process in a reactor. Combustion of reactor combustion chamber from pyrolysis tube containing biomass by measuring temperature, time, amount of biomass, bio-charcoal and liquid smoke and calorific value of the bio-charcoal is done in laboratory of Mechanical Engineering University of Muhammadiyah Metro, and Polinela Laboratory. From the result of the research, the value of calorific biomass of rubber shell is 6661,549 cal / gr, with combustion time 270 minutes, the result of solids in pyrolysis tube is 47,6\%, for young coconut skin biomass in indonesia tilap 5388,561 cal / gr, with a combustion time of 225 minutes of solids in a pyrolysis tube of 33.3\%, and rice husk biomass in a heating value of 3626,482 cal / gr with a combustion time of 190 minutes of solids yield in a pyrolysis tube of $40,05 \%$.
\end{abstract}

Keywords: Combustion, Pyrolysis, Liquid Smoke, Charcoal, Biomass

Abstrak

Biomass merupakan salah satu sumber energi terbarukan yang banyak kita jumpai disekitar kita, dengan berbagai jenis. Biomassa dapat dikonversi ke berbagai bentuk energi salah satunya yaitu pembakaran pirolisis. Pirolisis merupakan suatu dekomposisi kimia bahan organik (biomassa) melalui proses pemanasan pada suhu tinggi yang terjadi tanpa atau sedikit oksigen. Hasil proses pirolisis berupa produk bio-arang dan asap cair. Setiap biomassa memiliki karaktristik dan komposisi bebeda-beda, sehingga jika dibakar tentunya akan menghasilkan suhu dan produk pirolisis yang berbeda pula. Tujuan penelitian ini adalah mengetahui pengaruh jenis biomassa terhadap karaktristik pembakaran, nilai kalor dan jumlah bio-arang serta asap cair yang dihasilkan. Metode penelitian ini yaitu dengan menggunakan limbah biomassa cangkang karet, kulit kelapa muda dan sekan padi. Biomassa dibakar dengan proses prolisis slow di dalam sebuah reaktor. Pembakaran pada ruang bakar reaktor dari tabung pirolisis yang berisi biomassa dengan mengukur suhu, waktu, jumlah biomassa, bio-arang dan asap cair serta nilai kalor pada bio-arang tersebut yang di lakukan di laboratorium Teknik Mesin Universitas Muhammadiyah Metro, dan Laboratorium Polinela. Dari hasil penelitian nilai kalor biomassa cangkang karet sebesar 6661,549 cal/gr, dengan lama pembakaran 270 menit, hasil padatan di dalam tabung pirolisis sebesar 47,6\%, untuk biomassa kulit kelapa muda di dapat nila kalor 5388,561 cal/gr, dengan lama pembakaran 225 menit hasil padatan di tabung pirolisis sebesar 33,3\% , dan biomassa sekam padi di dapat nilai kalor 3626,482 cal/gr dengan lama waktu pembakaran 190 menit hasil padatan di tabung pirolisis sebesar 40,0\%.

Kata kunci : Pembakaran, Pirolisis, Asap Cair, Arang, Biomassa,

\section{PENDAHULUAN}

Seiring dengan pertambahan penduduk dan pertumbuhan industri, maka penggunaan akan bahan bakar juga meningkat sehingga dapat berdampak pada naiknya jumlah konsumsi bahan bakar yang berakibat pada semakin menipisnya cadangan minyak bumi yang ada. Untuk menanggulangi hal tersebut perlu diupayakan penyediaan sumber-sumber energi baru dan terbarukan. 
Salah satu sumber energi terbarukan yang banyak ditemui disekitar kita yaitu biomassa. Biomassa merupakan jenis matrial organik yang dihasilkan dari proses fotosintetis. Biomassa berasal dari sisa tumbuh-tumbuhan atau sering disebut dengan limbah biomassa. Biomassa atau limbah pertanian memiliki keunggulan seperti lestari tidak akan habis, tersedia secara berlimpah, Ramah lingkungan (rendah atau tidak ada limbah dan polusi, Sumber energi bisa dimanfaatkan secara cuma-Cuma. Pengembangan biomasa sebagai sumber energi untuk substitusi bahan bakar bisa menjadi solusi untuk mengurangi beredarnya gas rumah kaca di atmosfer karena konsentrasi $\mathrm{CO}^{2}$ dalam atmosfer akan seimbang. Terkadang keberadaan biomassa disebagian tempat sangat tidak diinginkan karena merupakan limbah dan sangat menggangu lingkungan, karena keberadaan limbah biomassa dapat memicu terjadinya peningkatan degradasi lahan. Oleh karena itu limbah biomassa perlu diolah dan dimanfaatkan sebagai bahan bakar.

Biomassa berasal dari beberapa jenis sumber tumbuhan. Setiap biomassa memiliki karaktristik dan komposisi bebeda-beda. Seperti biomassa sekam padi memiliki ukuran butiran kecil dengan tekstur sedikit keras dan kadar air sedikit. Kemudian biomassa cangkang karet dengan bentuk bijian sedang dan tekstur keras. Selanjutnya biomassa kulit kelapa muda dengan bentuk bongkahan besar tapi berserat dengan kadar air yang tinggi $[1,2,3]$

Dalam perkembangan konversi biomassa menjadi bahan bakar, proses kimia termal lebih banyak digunakan dibandingkan dengan proses biokimia. Hal ini disebabkan waktu proses secara termal lebih singkat dibandingkan dengan proses biokimia dan juga efisiensi konversi yang pada umumnya diperoleh dari proses termal lebih baik, yaitu antara 60\% sampai dengan $80 \%$ [4]

Diantara beberapa cara pembakaran salah satunya yaitu secara pirolisis. Pirolisis merupakan suatu dekomposisi kimia bahan organik melalui proses pemanasan pada suhu tinggi yang terjadi dengan tanpa atau sedikit oksigen.

Pirolisis adalah proses pemanasan suatu zat tanpa adanya oksigen sehingga terjadi penguraian komponen-komponen penyusun, istilah lain dari pirolisis adalah penguraian yang tidak teratur dari bahan-bahan organik yang di sebabkan oleh adanya pemanasan tanpa berhubungan dengan udara luar. Hal tersebut mengandung pengertian bahwa apa bila biomassa dipanaskan tanpa berhubungan dengan udara dan diberi suhu yang cukup tinggi, Maka akan terjadi penguraian [5]. Peroses pirolisi didefinisikan sebagai degradasi termal dari matrial padat (biomassa) pada kondisi udara /oksigen terbatas dan dari proses ini dihasilkan gas, tar dan char [6].
Pada proses pirolisis, perbandingan persentase ketiga produk tersebut char (berwujud pada), tar (berwujud cairan) dan gas sangat tergantung pada beberapa kondisi operasi, di antaranya adalah temperatur akhir proses pirolisis dan lama penahanan temperatur akhir (bolding time).

Proses pirolisis yang dilakukan yaitu bahan biomassa dimasukkan kedalam ruang pembakaran dan nyalakan api hingga biomassa terbakar keseluruhan lalu memanaskan tabung pirolisis. Reaksi yang terjadi pada tabung pirolisis pada suhu $0^{0} \mathrm{C}-200^{\circ} \mathrm{C}$ adalah reaksi endotermis, yaitu reaksi yang menyerap panas.

Sehingga biomassa menjadi meningkat suhu nya pada proses ini di atas $200^{\circ} \mathrm{C}$ yaitu pada tahap suhu tinggi merupakan reaksi eksotermis, yaitu reaksi yang menghasilkan panas artinya panas yang dihasilkan dari reaksi ini lebih besar dari yang diterima. Sehingga membuat biomasa menjadi arang.

Untuk menghitung persentasi biomassa di dalam tabung pirolisis di gunakan rumus sebagai berikut [7]:

$$
\text { Persentase padatan sisa }=\frac{W_{f}}{W_{i}} \times 100 \%
$$

Keterangan :

$$
\begin{aligned}
W_{f} & =\text { Sisa padatan }(\mathrm{kg}) \\
W_{i} & =\text { Berat awal biomassa }(\mathrm{kg})
\end{aligned}
$$

Tujuan penelitian ini adalah menemukan suatu energi pengganti yang dapat diperoleh dari sumbersumber atau bahan-bahan yang siklus pembaharuannya tidak memerlukan waktu yang terlalu lama yang disebut sebagai energi alternatif.

\section{METODE PENELITIAN}

Bahan baku biomassa yang digunakan dalam penelitian ini adalah biomassa cangkang karet, kulit kelapa muda dan sekan padi yang banyak di jumpai di Indonesia. Peralatan yang digunakan yaitu seperangkat reaktor pirolisis, tabung pirolisis dan kondensor, termokopel, Termometer laser. Produk yang dihasilkan arang aktif dan asap cair. Hasil tersebut diuji di lab kimia untuk mengetahui nilai kalor dan unsur kandungan kimia lainnya.

\section{Prosedur pengujian alat}

a. Siapkan peralatan yang akan digunakan dan bahan-bahan seperti cangkang karet, kulit kelapa muda, dan sekam padi.

b. Mempersiapkan alat ukur termokopel, timbangan,tabung reaktor dan tabung pirolisis. 
c. Masukan bahan biomassa ke dalam tabung pirolisis kemudian di bakar dengan bahan bakar biomassa itu sendiri diantara lain dengan cangkang karet lalu kulit kelapa muda dan kemudian sekam padi.

d. Catat hasil pengukuran suhu pada termokopel pada tiap-tiap titik setiap perubahan waktu 15 menit

e. Perhatikan proses pendinginan asap cair hingga tetesannya keluar dan tunggu hingga tetesan tersebut benar-benar berhenti dan tidak keluar lagi.

f. Setelah selesai, keluarkan arang dari Tabung Pirolisis lalu dinginkan, kemudian timbang massa arang dan asap cair yang didapat.

g. Lakukan pengujian dengan bahan biomassa yang lainnya dengan cara yang sama.

h. Bio-arang yang didapat diuji dilab kimia untuk mengetahui kadar nilai kalor, kadar air dan kadar abu.

i. Dan asap cair juga diuji di lab kimia untuk mengetahui unsur kandungan $\mathrm{pH}$, lignin dan asam asetat.

\section{HASIL DAN PEMBAHASAN}

Setelah melakukan pengujian maka didapat data-data hasil proses pirolisis dengan menggunakan tiga bahan baku yaitu Cangkang karet, Kulit kelapa muda dan Sekam padi seperti terlihat pada Tabel 1.

Tabel 1. Jumlah berat berbagai biomassa

\begin{tabular}{cccc}
\hline NO & Bahan & Berat awal & jumlah arang \\
\hline 1 & cankang karet & $4,8 \mathrm{~kg}$ & $2,3 \mathrm{~kg}$ \\
& kulit kelapa & & \\
2 & muda & $4,2 \mathrm{~kg}$ & $1,8 \mathrm{~kg}$ \\
3 & Sekam Padi & $2,9 \mathrm{~kg}$ & $1.3 \mathrm{~kg}$ \\
\hline
\end{tabular}

Tabel 2. Suhu pengujian bahan sekam padi

\begin{tabular}{cccc}
\hline NO & $\begin{array}{c}\text { Waktu } \\
\text { (Menit) }\end{array}$ & $\begin{array}{c}\text { T1 } \\
\text { Suhu Api } \\
\left({ }^{\circ} \mathbf{C}\right)\end{array}$ & $\begin{array}{c}\text { T2 } \\
\text { Tabung } \\
\text { Pirolisis }\left({ }^{\circ} \mathbf{C}\right)\end{array}$ \\
\hline 1 & 1 & 35 & 36 \\
2 & 20 & 120 & 80 \\
3 & 40 & 156 & 230 \\
4 & 60 & 198 & 447 \\
5 & 80 & 227 & 431 \\
6 & 100 & 220 & 385 \\
7 & 120 & 231 & 390 \\
8 & 140 & 231 & 427 \\
\hline
\end{tabular}

\begin{tabular}{cccc}
\hline 9 & 160 & 248 & 416 \\
10 & 180 & 262 & 394 \\
11 & 200 & 261 & 359 \\
12 & 220 & 277 & 317 \\
\hline
\end{tabular}

Tabel 3. Suhu pengujian bahan cangkang karet

\begin{tabular}{cccc}
\hline NO & $\begin{array}{c}\text { Waktu } \\
\text { (Menit) }\end{array}$ & $\begin{array}{c}\text { T1 } \\
\text { Suhu Api } \\
\left({ }^{\circ} \mathbf{C}\right)\end{array}$ & $\begin{array}{c}\text { T2 } \\
\text { Tabung } \\
\text { Pirolisis }\left({ }^{\circ} \mathbf{C}\right)\end{array}$ \\
\hline 1 & 1 & 32 & 32 \\
2 & 20 & 99 & 99 \\
3 & 40 & 115 & 123 \\
4 & 60 & 137 & 159 \\
5 & 80 & 182 & 180 \\
6 & 100 & 207 & 205 \\
7 & 120 & 249 & 230 \\
8 & 140 & 280 & 274 \\
9 & 160 & 249 & 277 \\
10 & 180 & 246 & 377 \\
11 & 200 & 261 & 393 \\
12 & 220 & 277 & 392 \\
13 & 240 & 283 & 387 \\
14 & 260 & 297 & 308 \\
15 & 270 & 307 & 314 \\
\hline
\end{tabular}

Tabel 4. Suhu pengujian bahan kulit kelapa muda

\begin{tabular}{cccc}
\hline NO & $\begin{array}{c}\text { Waktu } \\
\text { (Menit) }\end{array}$ & $\begin{array}{c}\text { T1 } \\
\text { Suhu Api } \\
\left({ }^{\circ} \mathbf{C}\right)\end{array}$ & $\begin{array}{c}\text { T2 } \\
\text { Tabung } \\
\text { Pirolisis }\left({ }^{\circ} \mathbf{C}\right)\end{array}$ \\
\hline 1 & 1 & 39 & 33 \\
2 & 20 & 92 & 49 \\
3 & 40 & 115 & 85 \\
4 & 60 & 122 & 84 \\
5 & 80 & 130 & 90 \\
6 & 100 & 131 & 105 \\
7 & 120 & 139 & 112 \\
8 & 140 & 149 & 122 \\
\hline
\end{tabular}




\begin{tabular}{cccc}
\hline 9 & 160 & 151 & 162 \\
10 & 180 & 172 & 189 \\
11 & 200 & 202 & 208 \\
12 & 220 & 219 & 255 \\
13 & 240 & 200 & 254 \\
14 & 260 & 184 & 221 \\
15 & 280 & 175 & 203 \\
\hline
\end{tabular}

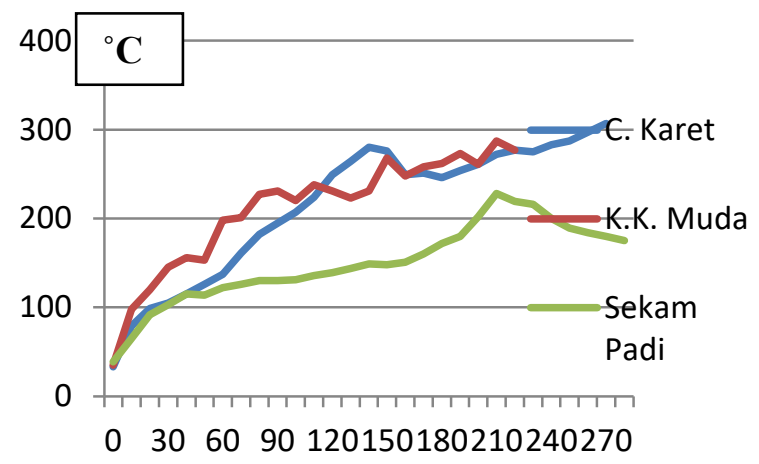

Gambar 1. Suhu api dan waktu pembakaran berbagai biomassa

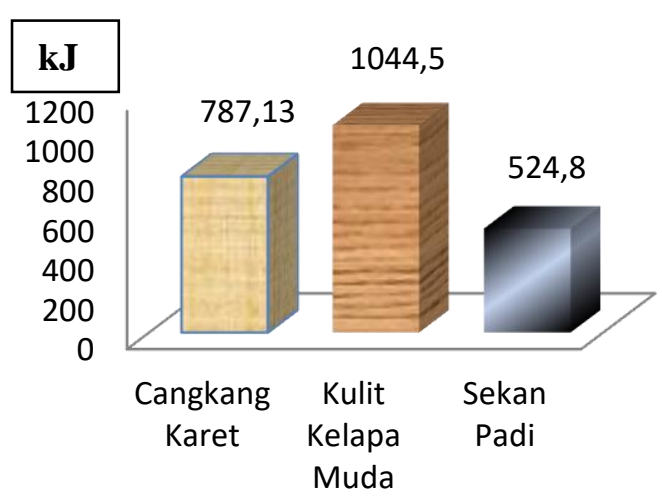

Gambar 2. Grafik energi penyerapan air condenser dari berbagai biomassa

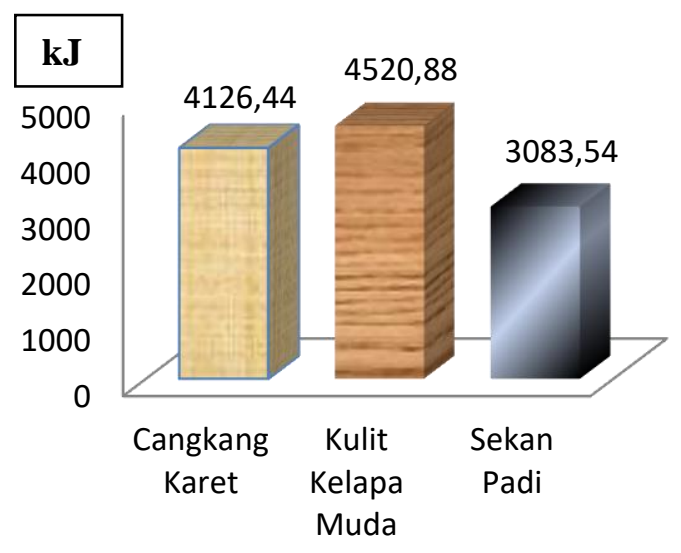

Gambar 3. Grafik energi pembakaran dari berbagai biomassa

Dari hasil pengujian didapat seperti pada gambar 1, terlihat bahwa cangkang karet memiliki suhu pembakaran yang paling tinggi yaitu $307^{\circ} \mathbf{C}$ dan waktu pembakaran juga lama yaitu 270 menit jika dibandingkan dengan bahan kulit kelapa muda dengan suhu $277^{\circ} \mathbf{C}$ dan waktu 190 menit, juga pada sekam padi dengan suhu yang dihasilkan yaitu $219^{\circ} \mathbf{C}$ tapi waktunya cukup lama yaitu 225 menit. Pembakaran tersebut terjadi dikarenakan cangkang karet memiliki tekstur yang keras sehingga dapat menghasilkan pembakaran yang baik dibandingkan kulit kelapa muda dan sekam padi.

Untuk sekam padi karena bentuknya yang kecil dan tersusun rapat sehingga pembakaran agak sulit terjadi karena udara agak susah susah masuk ke selasela sekam padi sehingga suhu pembakarannya kecil dan juga pembakaran hanya menghasilkan bara api dan bukannya api.

Untuk suhu pembakaran pada kulit kelapa muda memiliki suhu yang tinggi yaitu $277^{\circ} \mathrm{C}$ namun waktu yang singkat yaitu 225 menit jika dibandingkan dengan cangkang karet dan sekam padi karena kulit kelapa memiliki bentuk yang besar dan berserat sehingga muda dan cepat terbakar. Tetapi untuk sekam padi memiliki suhu yang lebih rendah dibandingkan cangkang karet kerena tekstur yang kurang keras.

Untuk suhu biomassa kulit kelapa muda terjadi peningkatan pada setiap menitnya karena mudah terbakar dan nilai temperatur tertingginya dimenit 210, dan waktu pembakaran lebih cepat karena tekstur yang lunak dan berserat sehingga mudah terbakar di banding biomassa cangkang karet dan sekam padi. Perbandingan suhu pembakaran yang sangat berbeda dari menit 30 sampai 90 dikarenakan biomassanya mudah terbakar sehingga suhu ditabung pirolisis dapat cepat naik.

Dari menit 30 sampai 240 cangkang karet mengalami peningkatan terus menerus dikarenakan cangkang karet pada ruang bakar tarjadi temperatur yang sangat tinggi sehingga berpengaruh pada tabung pirolisis. Setelah temperatur pada ruang bakar turun maka tempratur tabung ikut turun pada menit 270 .

Sedangkan suhu sekam padi yang terjadi cukup kecil yaitu $219^{\circ} \mathrm{C}$. Hal ini sangat berbeda di banding dengan biomassa yang lainnya, sehingga suhu di ruang bakar mengalami kenaikan yang cukup lama yang kemudian berpengaruh pada suhu tabung pirolisisnya.

Berbagai karaktristik lainnya yaitu : 
a. Energi pembakaran pada pengujian berbagai biomassa.

Energi pembakaran yang terjadi seperti pada gambar 4 menunjukan bahwa cangkang karet memiliki energy yang paling besar yaitu 1044,5 $\mathrm{kJ}$ jika disbanding dengan yang lainnya, diikuti kulit kelapa muda 4126,44 kJ dan bambu 3083,54 kJ yang paling kecil. Hal ini karena cangkang karet lebih keras, dan kulit kelapa muda cepat terbakar.

b. Energi yang diserap air kondensor pada pengujian berbagai biomassa.

Untuk energi penyerapan air kondensor terjadi peningkatan yang sama seperti pada energi pembakaran dimana cangkang karet memiliki penyerapan tertinggi $1044,5 \mathrm{~kJ}$, diikuti kulit kelapa muda 787,13 kJ dan bambu 524,8 kJ seperti pada gambar 5 .

c. Suhu dan waktu pembakaran tertinggi tiap biomassa

1) Biomassa cangkang karet : $T_{\max }=307^{\circ} \mathrm{C} ; t=270$ menit

2) Biomassa kulit kelapa muda : $T_{\max }=277^{\circ} \mathrm{C} ; t=225$ menit

3) Biomassa sekam padi :

$$
T_{\max }=219^{\circ} \mathrm{C} ; t=190 \text { menit }
$$

d. Persentase jumlah hasil padatan arang pada tiaptiap biomassa yaitu :

$$
\mathrm{PS}=\frac{W_{f}}{W_{i}} \times 100 \%
$$

1) Persentase padatan arang cangkang karet

$$
\begin{aligned}
& \text { PS }=\frac{2,3}{4,8} \times 100 \% \\
& \text { PS }=47,9 \%
\end{aligned}
$$

2) Persentase padatan arang kulit kelapa muda

$$
\begin{aligned}
& \mathrm{PS}=\frac{1,8}{4,2} \times 100 \% \\
& \mathrm{PS}=42,9 \%
\end{aligned}
$$

3) Persentase padatan arang sekam padi

$$
\begin{aligned}
& \mathrm{PS}=\frac{1,3}{2,9} \times 100 \% \\
& \mathrm{PS}=44,8 \%
\end{aligned}
$$

Rendemen merupakan salah satu parameter yang penting untuk mengetahui hasil dari suatu proses. Bioarang pada penelitian ini dihasilkan melalui proses pembakaran pirolisis di reaktor pirolisis. Bedasarkan hasil yang didapat tersebut bahwa arang cangkang karet menghasilkan arang yang lebih banyak yaitu 47,9\% lalu sekam padi 44,8\% dan kulit kelapa muda $42,9 \%$, hal ini dikarenakan semakin keras biomassa maka semakin banyak arang yang dihasilkan dan sedikit abu. Sebaliknya semakin lunak biomassa maka semakin sedikit arang dan banyak abu dihasilkan seperti kulit kelapa muda.

Tabel 5. Hasil pengujian nilai kalor Biomassa

\begin{tabular}{|c|c|c|}
\hline NO & Bahan & Nilai kalor (Cal/gr) \\
\hline 1 & Cangkang karet & 6661,549 \\
\hline 2 & Kulit kelapa muda & 5388,561 \\
\hline 3 & Sekam Padi & 3626,482 \\
\hline
\end{tabular}

Berdasarkan hasil pengujian laboratorium (Tabel 5) menunjukan bahwa nilai kalor biomassa yang tertinggi juga dari cangkang karet sebesar 6661,549 Cal/gr. Untuk kulit kelapa muda nilai kalornya sedikit lebih besar yaitu 5388,561 Cal/gr, dibanding sekam padi yaitu 3626,482 $\mathrm{Cal} / \mathrm{gr}$. Ternyata tekstur yang keras dapat menunjukan nilai kalor yang besar dibanding yang lunak.

Pengujian nilai kalor dari hasil pirolisis menggunakan biomassa cangkang karet dengan lama waktu pembakaran 270 menit menghasilkan nilai kalor yang lebih besar, sedangkan untuk pengujin nilai kalor kulit kelapa muda dengan lama waktu pembakaran 225 menit menghasilkan nilai kalor yang hamper sama hasil pengujian nilai kalor pada bambu sedikit lebih kecil.

Tabel 6. Hasil asap cair dari berbagai biomassa

\begin{tabular}{|c|c|c|c|}
\hline Biomassa & $\begin{array}{c}\text { Kulit kelapa } \\
\text { muda (gr) }\end{array}$ & $\begin{array}{c}\text { Sekam } \\
\text { padi (gr) }\end{array}$ & $\begin{array}{c}\text { Cangkang } \\
\text { karet (gr) }\end{array}$ \\
\hline $\begin{array}{c}\text { Jumlah } \\
\text { Bio-oil }\end{array}$ & 308 & 284 & 246 \\
\hline
\end{tabular}

Jumlah rendemen asap cair yang dihasilkan pada proses pirolisis sangat bergantung pada jenis bahan baku yang digunakan. Persentase rendemen yang diperoleh juga sangat bergantung pada sistim kondensasi yang dipakai. Kondisi ini sesuai dengan yang dikemukakan Tranggono et al (1996), bahwa untuk pembentukan asap cair digunakan air sebagai medium pending in agar proses pertukaran panas dapat terjadi dengan cepat.

Pirolisis pada suhu yang terlalu tinggi dan waktu yang terlalu lama akan menyebabkan pembentukan asap cair berkurang karena suhu dalam air pendingin semakin meningkat sehingga asap yang 
dihasilkan tidak terkondensasi secara sempurna. Proses kondensasi akan berlangsung optimal apabila air di dalam sistirn pendingin dialiri secara kontinyu sehingga suhu dalam sistim terse but tidak meningkat. Hal ini sesuai dengan pernyataan Demirbas (2005) bahwa asap cair hasil proses pirolisis bahan kayu dapat dihasilkan secara maksimum j ika proses kondensasinya berIangsung secara sempurna.

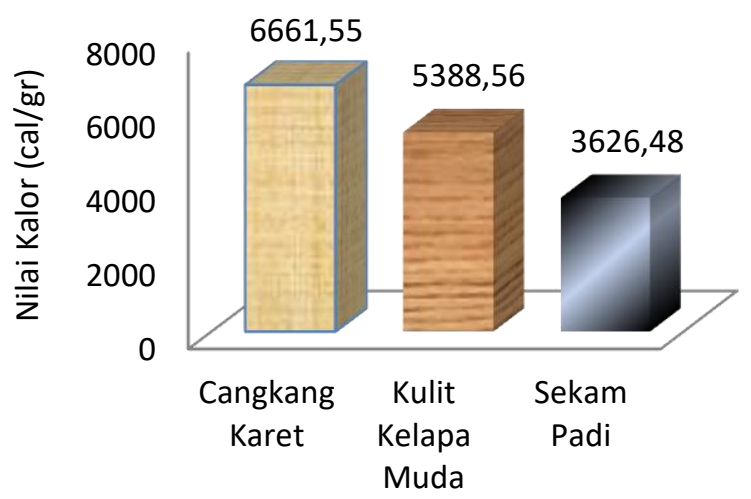

Gambar 4. Nilai kalor berbagai arang biomassa

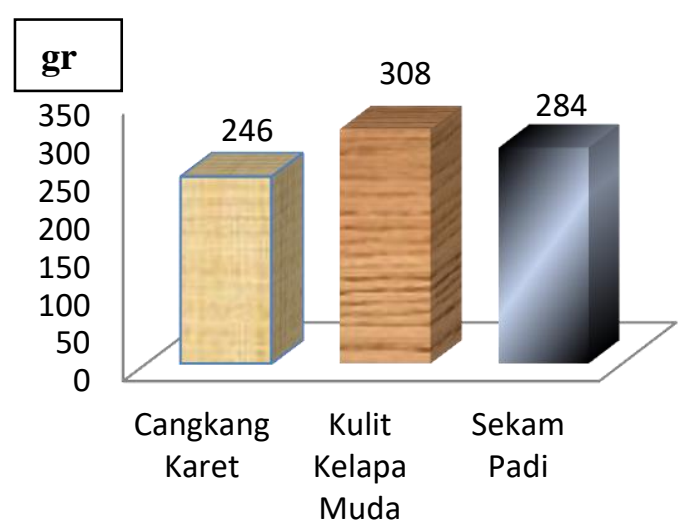

Gambar 5. Jumlah asap cair yang dihasilkan dari berbagai biomassa

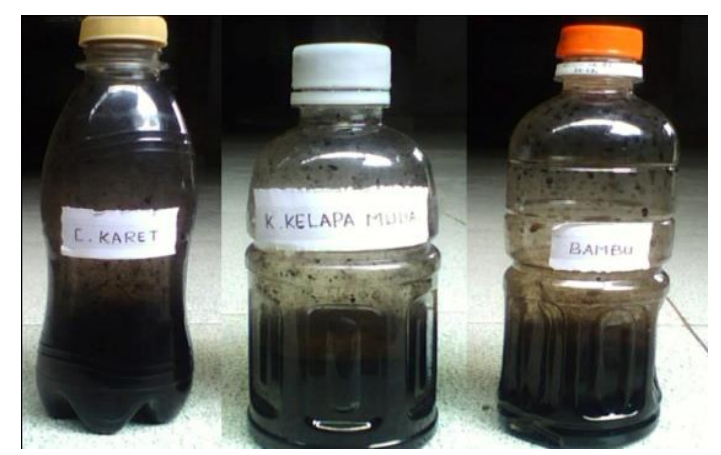

Gambar 6. Asap cair dari berbagai biomassa

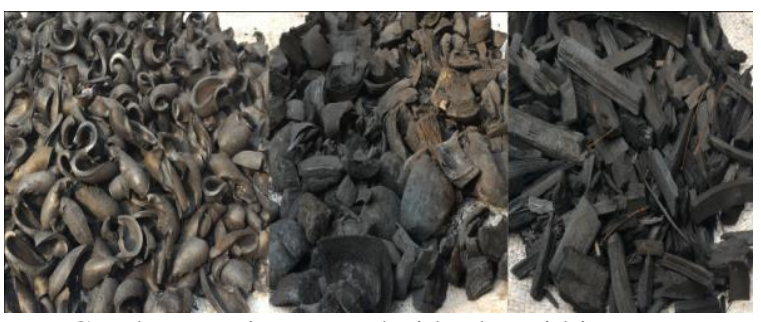

Gambar 7. Bio-arang dari berbagai biomassa

Dari Gambar 6, grafik jumlah asap cair terlihat bahwa bahan cangkang karet menghasilkan jumlah asap cair yang lebih sedikit 246 gr dibandingkan kulit kelapa muda 308 gr dan sekam padi 284 gr hal ini dikarenakan semakin tinggi suhu maka semakin banyak asap cair yang dihasilkan. dan semakin tinggi suhunya maka akan semakin banyak padatan biomassa yang teroksidasi dan terurai menjadi asap dan pada gilirannya menjadi cairan.

Pada gambar 4, terlihat bahwa peningkatan nilai kalor arang yang beriringan dengan peningkatan suhu pirolisis dapat diakibatkan karena peningkatan suhu pirolisis meningkatkan penguapan volatile matter sehingga mengakibatkan penurunan kadar air dan menyisakan karbon pada arang sehingga berakibat pada peningkatan nilai kalor arang tersebut. Hal in sesuai dengan penelitian (Raju, 2016).

\section{KESIMPULAN}

Berdasarkan hasil penelitian tersebut maka dapat di simpulkan sebagai berikut :

1. Hasil pengujian nilai kalor pada biomassa

a. Hasil pengujian pirolisis pada arang biomassa cangkang karet di hasilkan nilai kalor sebesar $6661,549 \mathrm{cal} / \mathrm{gr}$.

b. Hasil pengujian pirolisis pada arang bimassa kulit kelapa muda di hasilkan nilai kalor sebesar 5388,561 cal/gr.

c. Hasil pengujian pirolisis pada arang biomassa bambu di hasilkan nilai kalor sebesar 3626,482 cal/gr.

2. Karakter pirolisis pada bahan biomassa

a. Proses pengujian prolisis menggunakan biomassa cangkang sebanyak $4,8 \mathrm{~kg}$ menjadi bio-arang $2.3 \mathrm{~kg}$ dengan lama pembakaran 270 menit, temperatur tertinggi di ruang bakar $307{ }^{\circ} \mathrm{C}$

b. Proses pengujian biomassa kulit kelapa muda dengan berat $4,2 \mathrm{~kg}$ menjadi bioarang $1,4 \mathrm{~kg}$ dengan lama waktu 
pembakaran 190 menit, temperatur tertinggi di ruang bakar $277^{\circ} \mathrm{C}$

c. Proses pengujian prolisis mengunakan biomassa sekam padi dengan berat $4,0 \mathrm{~kg}$ pada ruang bakar berkurang menjadi bioarang $1,3 \mathrm{~kg}$ dan lama pembakaran 225 menit, temperatur tertinggi di ruang bakar $219^{\circ} \mathrm{C}$

3. Hasil asap cair yang didapat dari jenis biomassa cangkang karet 240 gr, biomassa kulit kelapa muda 308 gr dan biomnassa sekam padi 284 gr.

\section{DAFTAR PUSTAKA}

[1] Fardian F. 2014. Pengaruh temperatur dan komposisi pada pembuatan biobriket dari cangkang buah karet dan plastik polietilen. Jurnal Teknik Kimia. Universitas Sriwijaya Palembang.

[2] Palungku., 2001, Aneka Produk Olahan Kelapa, Cetakan ke Sembilan, Penebar Swadaya, Jakarta.

[3] Wada, S., W. Mosungnoen, K. Hemachandra and H. Jarunworaluck. 2005. Survey of the Research on the Utilization of Rice Husk and Rice Husk Silica. Proceeding of the First Workshop on the Utilization of Rice Husk and Rice Husk Silica, September 19, 2005. Chulalangkorn University Thailand.

[4] The Japan Institute of Energy. 2008. Buku panduan biomassa Asia : panduan untuk produksi dan pemanfaatan biomassa. Japan : Kementrian Pertanian, Kehutanan, dan Perikanan.

[5] Wijayanti, Widya. Nur, Mega Sasongko. Dkk., 2013, Metode Pirolisis Untuk Penanganan Sampah Perkotaan Sebagai Penghasil Bahan Bakar Alternatif, Jurnal Rekayasa Mesin, Vol.4, No.2, ISSN 0216-468X, Hlm. 85-92

[6] Balasi, 2008. Modeling chemical and physical processes of wood and biomassa pyrolisis, program in energy and combustion science 34,47-99

[7] Belonio, 2005.Rice Husk Gas Stove Hand Book, Departement Of Agriculturar engenering And Enviromental Managemen College of agriculturar Central Philippine University Lioilo City, Philippine. 
